\title{
Public park in small resort town on the example of Supraśl ${ }^{1}$
}

\author{
Dorota Gawryluk
}

Zespót Dydaktyczny Architektury Krajobrazu, Politechnika Białostocka

Marta Baum

Katedra Konstrukcji Budowlanych i Architektury, Politechnika Białostocka

\section{Jurga Kucinskiene}

\begin{abstract}
The aim of our science work and project was to create a functional program for a public park appropriate for a small resort town like Supraśl. Such area should incorporate elements of healing and sensory gardens. Results of numerous analyses of the Public Park in Supraśl (former Saski Garden) were presented for the specific setting of Supraśl. The proposed functional program was developed on the basis of architecture students' projects completed in the academic year of 2016/2017 at Bialystok University of Technology in cooperation with the Municipal Office and the Mayor of Supraśl. The analysis of the completed work shows that it is possible to contain a rich functional program, appropriate for both the citizens of Supraśl and the patients of the resort, in the area of the former Saski Garden. It could be done without any loss to its historical and natural value.
\end{abstract}

Key words: public park, resort, healing garden, children garden, Supraśl

The urban park (also called Saski park) in Supraśl was created at the beginning of 19th century. Its setting up was closely linked to the development of the textile colony in this town by Wilhelm Zachert [Bończak-Kucharczyk i in. 2000; Bończak-Kucharczyk, Maroszek www.]. The factory owner in 1837 rented from the tsar's authorities the lands taken from the basilian monks that were located on the southern part of the convent and bordering with the old colony [Dobrowolski, Popławska 2003]. Zachert was the father of the idea of the new town which spatial structure was made in the classic style. The carcass of the organized composition was Główna Street (now $3^{\text {rd }}$ of May street) which axis linked the church with the town hall square. Regular urban structure was filled in with the parallel Ogrodowa Street, finished with the building of the protestant community. In the town space main streets were closed by dominant churches' towers and their frontal was the regular building called textile's house [Łodziński 2002; Supraśl 500 lat, 2000].

The classical town's idea was based on the linking the urban structure with the park and finally with the attractive landscape. Filling in the buildings and the space with green in the form of private gardens and the Urban Park was developed in the direction of the valley of the river Supraśl, Knyszyńska Forest and the Bazylian's convent.

In 19th century in Supraśl was created a kind of flora to improve the health's conditions. The Town's Park was created on the north part of Ogrodowa Street in the place of the abandoned alder forest, that wasn't possible to construct on. Next to green space, from the north with old Italian gardens in the Bazylian's convent (Fig. 1a), on the corner with the green square between the church and the convent and from the south with the private Bucholtz's garden created in the beginning of 19th century. The park's scenery was linked to the protestant community cloister and the protestant school and nearby Basylian's convent. Inside the park there were two roundabouts crossed by the simple walking paths, guiding you towards the corners, streets and other special 
solutions in the park (Fig. 1b). In 1925 The Town Park was given to the local authorities by Zachert's family. Later it was remade in the modern style. In the western side was set up a memorial in the form of the obelisk with the hawk and the walking paths were changed according to the style, moreover the bypass road was created. In 1934-35 in the eastern part of the park a town's stadium was built, which occupied half of the park's area breaking the previous structure [Bończak-Kucharczyk i in. 2000; Bończak-Kucharczyk, Maroszek www.] (Fig. 1c).
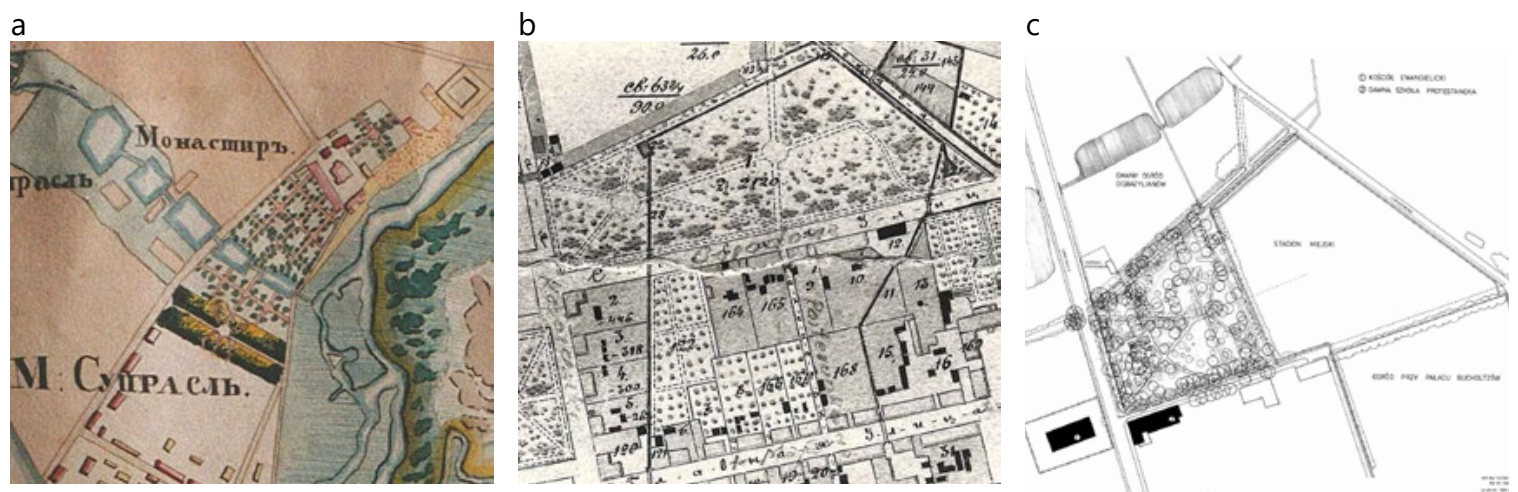

Fig. 1. Historical maps of Supraśl: a - Garden in the Bazylian's convent in 1845 [Dobrowolski, Popławska 2003]; b - The Town Park in Supraśl in 1892 [Bończak-Kucharczyk i in. 2000; Bończak -Kucharczyk, Maroszek www.]; c - The Town Park in Supraśl in 1988 [Bończak-Kucharczyk i in. 2000; Bończak-Kucharczyk, Maroszek www.].

After the Second World War in the park's space some maintenance works took place. During the next decades its structure started slowly disappearing among the old trees and the new grown vegetation [Bończak-Kucharczyk i in. 2000; Bończak -Kucharczyk, Maroszek www.]. The light space in the park was covered by the dark, welter tall trees fighting for the light. There was build playground for children in 2001 next to Park on its north side. The football court was modernized in 2009 and build in standard form of "Orlik" court.

In 2016 there was a hurricane in Supraśl which destroyed buildings and the green space in the town. In the Town's Park as the result many trees were broken down (about 45 old trees) [Januszkiewicz 2017b]. Especially the south-western part suffered the most, this part was perfectly composed with the church and the old school (now the Town Hall). The trees' destruction was the reason for beginning the process of the restoration of this old park. In the close future, except the historical values, the Saski Garden should conserve the values of the public park responding the citizens' needs but also the new curative needs due to the town's characteristics, as it is visited by the patients and tourists.

Based on the cooperation of the City Council in Supraśl and Bialystok University of Technology together with second grade students on Landscape Architecture in the winter term 2016/17 the science studies in cooperation with lecturers, on the functional renovation of the park started [Supraśl www. 2016].

\section{The aim, range and the state of the studies}

The aim of the work is to find the program of the functionality of the Town's Park in Supraśl. The complexity of the issue is due to historical roots of Supraśl together with the historical space composition, adding the natural position of the town in the valley of Supraśl river and moreover recently this city achieved the status of the health resort (in 2015). Therefore the Town Park is analyzed taking into consideration different conditions, historical and how to integrate it with the historical, environmental town's landscape and at the same time taking into account its availability to different kinds of users (citizens, tourists and patients). Therefore, in this work the most attention was paid to issues as historical, resort, therapeutic and jordanowski character of the park linked to the idea that it must be a public park in Supraśl. Analyzing students' projects made by Bialystok University of Technology students, Landscape Architecture of master degree, made the possibility of broadening the functional park's programme with new areas. The solutions from the theoretical studies can 
be the basis to define the ideas of the functional programme guiding us towards the restoration of the park after the hurricane in June in 2016.

The complexity of the study was linked to the literature analysis associated with the vast problematic of the issue composed of the historical past of Supraśl [Dobrowolski 2003; Dobrowolski, Popławska 2003; Łodziński 2002; Supraśl 500 lat, 2000] and Town's Park [Bończak-Kucharczyk i in. 2000; Bończak-Kucharczyk, Maroszek www.] and the historical background associated with the public parks in Poland and the region [Ciołek 1978; Majdecki 2007, 2009; Zachariasz 2006; Łakomy 2012; Gawryluk 2015]. One of the issues is the protection and conservation of the historical gardens [Bogdanowski 1999; Majdecki1993] and their revalorization in the light of Florence Card [Zachariasz 2008]. Its development takes into account the possibility to fill in the structure of the city gardens with the areas and functions accompanying them such as the playground according to the jordanowskie's gardens idea [Czałczyńska-Podolska 2016] therapeutic 'gardens [Pudelska I in. 2016; Souther-Brown 2015; Winterbottom, Wagenfeld 2015; Dmitruk 2015] or assuring the free access to the different groups of people [Dąbski, Dutkiewicz 2010; Kłopotowska, Kłopotowski 2017; Kłopotowski 2017]. Another problem associated with Supraśl is the issue of the resort-spa shown in the literature we only find few mentioning of this topic [Węcławowicz-Bilska 2008a, 2008b] but is vastly described in the scientific articles showing the concrete centers or spa parks [Piróg 2011; Piróg 2013; Myczkowski, Rymsza-mazur 2012; Rutyna 2014; Czubiński 2015; Leniartek 2015].

\section{The Town Park}

The public parks, as public green space where you have a limitless access, were set up in Europe at the beginning of the $19^{\text {th }}$ century, but in the second part of the 20 century they bloomed. In Poland in $17^{\text {th }}-18^{\text {th }}$ century [Majdecki 2007, 2009] private gardens were opened for the visitors . Aristocracy let people visit their private gardens. The oldest ones come from the beginning of 19th century.

The town Park in Supraśl is one of the oldest parks in the region in the frontiers of podlaskie province [Bończak-Kucharczyk i in. 2000; Bończak-Kucharczyk, Maroszek www.]. It was paid by a private investor Whilhelm Zachert but it was planned as a public space and finally it was given to the town in 20ies of 20th century. During many years both the shape and the size (the paths, roundebouts localization, trees, bushes and perennials compositions, ponds system, materials and the equipment) has been changed. The only thing that hasn't been changed was the meaning of the park to the urban-environmental composition of the city and environmental picture of Supraśl. The most important issue has been the function of the public garden opened for everyone.

Nowadays is nearly impossible to talk about the historical space composition of the park from Zachert's times designed on the basis of the Bazylian's Italian garden, communicated with the fragments of the convent's gardens, in the twenties of 20st century was reduced and recomposed. After the Second World War the green spaces became denser due to the sef-seeders which made the degradation of the garden possible.

In the light of the recent researches, the documents and archival plans, it is hard to talk about the possibility of restoring the Town Park in Supraśl. It's better to talk about adapting the park to the modern functions based on the cannons of the conservation laws of the historical gardens [Majdecki 1993] and the basis of the Florence Card [Zachariasz 2008] and the Florence convention [Myczkowski, Rymsza-Mazur 2012]. In their context the revalorization works that can be put into practice should be inspired by the town's history. For the time being the knowledge of the changes in the park's composition don't let its restructuration (neither the Basylian's Italian garden). Maybe in the future due to archeological studies it will be possible.

The main guideline of the park's revalorization is the protection of the individual characteristics together with the communication and view solutions towards the town's scale and Supraśl panorama. We can also agree with professor Majdecki about the limited identity of the Town Park in the cultural- environmental space of Supraśl. In the age of the globalism and unification the issue of the limited identity is the highest form of the usage of the cultural heritage including the historical gardens and historical view [Majdecki 1993]. We must remember not to over invest which is often the reason for suggesting too many ideas. Adapting the garden to the modern needs based on the improvement of technical and functional solutions, introducing new leisure places for both active and non-active rest, introducing new services can't cause the lost of the individual worth of the monument [Majdecki 1993]. The Florence Card says that the conservation of the garden is its usage. 
[Zachariasz 2008] But it must be used correctly and when the proposed function (e.g. the playground or park for the domestic animals which can cause the chaos due to noise) can't go with the idea of the monumental side of the park, which can't be localized in its neighborhood so that doesn't ruin its historical value.

\section{The Spa Park}

Architectonic style of the spa building has become stable in the last 200 years and to the great extend it was the consequence of the type of spa curing but also individual cultural characteristics and environmental landscape of the spa places [Leniartek]. It was associated with the localization of the permanent environmental spa installations in the center of the town, integrated in the representations of the green spaces (parks, paths, promenades, squares, gardens ...). This spa center was a part of the neighboring parks areas and forest ones too [Węcławowicz-Bilska 2008a, 2008b]. Main characteristics that distinguished the spa partks from the town ones, squares or green spaces are its representation and composition in the scale of the bases of the spa conditions [ akomy 2012]. They were the attractive and aesthetic frame of the process of curing of those buildings (walking halls, drinking rooms, resorts, inhalation rooms etc) and the active way of spending free time in the spa park (paths- walking, concert halls - listening, pavilions, theatres, spending the free time outside- a lot of benches) [Węcławowicz-Bilska 2008a]. The space composition of those ides assured both attractive views on the architecture and green spaces of the park as the special view solutions (interior and exterior) with the landscape of the town and region.

The future development of the spa places is linked to the transformation of the attitude towards the process of curing. The aim is to pay more attention towards the prevention of the illnesses such as civilization ones, cardiology disorders, stress, overweight or depression. Finally in the offer of spas appear new treatments aimed into younger patients [Kubecka 2016]. The offer based on the prevention is directed to even the pupils of the primary schools in form of green schools [Rutyna 2014].

Supraśl park in its localization and structure is already prepared to incorporate new objects and spaces, which will widen the spa offers in the town. Although, we must remember that new functions should be incorporated into the historical character of the park and taking into account the solutions already done on the environmental level.

\section{The healing park}

There is a long history of using gardens for their mental and physical support. Over the past 200 years or so we have designed towns and cities with parks and gardens to provide access to fresh air and exercise. Early gardens were designed to be sensory-rich. Their designers were mindful of the power of nature to heal, of the need for a local supply, and to provide gentle outdoor activity for all ages [Souter-Brown 2015]. The five basic senses of sight, smell, hearing, touch and taste were well accounted for. Healing gardens need to be an integral part of our modern framework. Early

Persian and later monastic gardens were fundamental part of their society and communities. Their role was a mix of spiritual, welfare, educational and healing [Winterbottom, Wagenfeld 2015]. While modern life has become more complex our basic needs remain unchanged. The contemporary health and well-being benefits of healing gardens spill over into education, crime prevention and social cohesion.

Healing landscape interventions can make a difference to longevity, quality of life, and the general well-being of communities. Local and central governments need to be adaptable and creative in their response to proactive urban design for healthy lifestyles [Souter-Brown 2015; Winterbottom, Wagenfeld 2015]. Through the development of healing, sensory and therapeutic gardens built into public open space we can ensure developments improve human health cost effective, functional and ultimately sustainable. It is difficult to live a healthy lifestyle without an appropriate environment. Well-designed healing garden can help to restore the balance of physical, mental and social well-being

In Europe in 21st century curing through the contact with the nature comes back as the integral part of the process of healing and rehabilitation [Pudelska I in. 2016]. In that sense healing gardens and sensory ones are the best form of the functional programme of the spa cities that can find their place in the revalorized space in The Town Park in Supraśl. 


\section{The accessible park}

In the last decades the accessibility of the public space is being promoted, including the public access to the green spaces to all kind of users. The special mentioning must be done about the adaptation of those public spaces to different disabilities. Because of difficulties disables people suffer, they are eager to enjoy those spaces such as healing, spa and sensory parks [Dąbski, Dutkiewicz 2010]. We should remember about the functional equipment (in the communication, water places, architectonical furniture, small architecture buildings) as well as information given (info boards, mockups prepared for different form of perception such as touch, hearing, limited sight) [Klopotowska, Kłopotowski 2017; Kłopotowski 2017]. Proper actions in that direction is associated with the integration of disables people to the society and in that sense improvement in both disables and not people's lives.

\section{The Jordan park}

At the end of XIX century doctor Henryk Jordan proposed his solution to the garden designed for the children where they can play outdoors [Majdecki 2009]. The concept of so called the jordanowski garden includes vast a programme of children spending their time outdoor more than a traditional concept of the playgrounds. It doesn't limit the space only to the play and activities based on typical installations, but also pays a lot of attention to the children bringing up and learning. In Cracow Jordan park didactical programme in the space the sculptures of the famous Polish people are incorporated but also activities such as gardening and woodwork. Sport activities for children can be done in the complex of football pitches, the winter skating place on the pond, or the gym hall. The very important element of the programme was the presence of the monitors who carried the activities with kids. [Majdecki 2009]. In the Jordan parks the activities for kids were offered all year round where the possibility of spending their free time outdoors together with their education was offered.

Nowadays the children gardens all over the world in their programmes offer all kinds of useful and didactical activities. As Magdalena Czałczynska-Podolska says Those kinds of gardens are organized as the children's farms, the butterflies gardens, the edible gardens, the story telling gardens, the water gardens, the memorial gardens end the sensory ones. Among the characteristics of those kinds of gardens we can discover the absence of typical playground installations, or the minimal presence of them, basing them on the natural materials, presence of edible plants, sensory solutions and integrating children in the creation and functioning of those spaces and the possibility of integrating disabled children in those places [Czalczynska-Podolska 2016].

In Supraśl Town Park there is a playground made recently. It is recommended to renew the existing one in order to offer a new educational place for them, inspired on the idea of Jordan gardens or the modern spaces for kids. The space conditions and environmental ones of the neighboring territories allow to put into practice the functional park based on the sensory and useful elements.

\section{The projects}

In November in 2016 the cooperation between the Town Council in Supraśl and Bialystok Polytechnic School started with the target to find the ideas for the functional park in Supraśl. The town offered the help in the didactical process in for of meetings with the mayor Radosław Dobrowolski and the officials representing different departments (Those meetings were prepared in a very attractive forms therefore we are extremely grateful to the mayor Radoslaw Dobrowolski, vice mayor Marek Sztuko, architects Agata Bielska and Andrzej Dudziński and inspektor Dorota Borecka). During those meetings the students were presented the plans of the town which included the idea of the park, the forest economy and social expectations in order to redesign the new Saski Garden.

Analyzing the literature, the studies and the stocktaking (October, November 2016) and analysis of different conditions (historical, localization, functional, demographic, environmental, ect.) allowed the students reach some design conclusions which became the basis of the idea of projects to revalorize the Town Park in Supraśl. Those projects were made as a part of the course Restoration designing in the winter term 2016/17 in the department of Landscape Designing in the faculty of Building and Environmental Engineering at Bialystok University of Technology responsible for designing Dorota Gawryluk and Marta Baum and for the studying 
the grounds Beata Matowicka and Zofia Tyszkiewicz (Supraśl). Students of master degree participated also in science work of department connected with Supraśl's park.

a

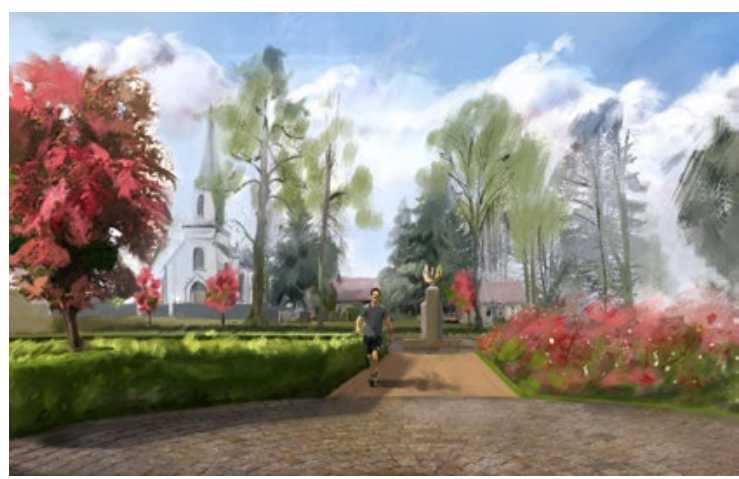

C

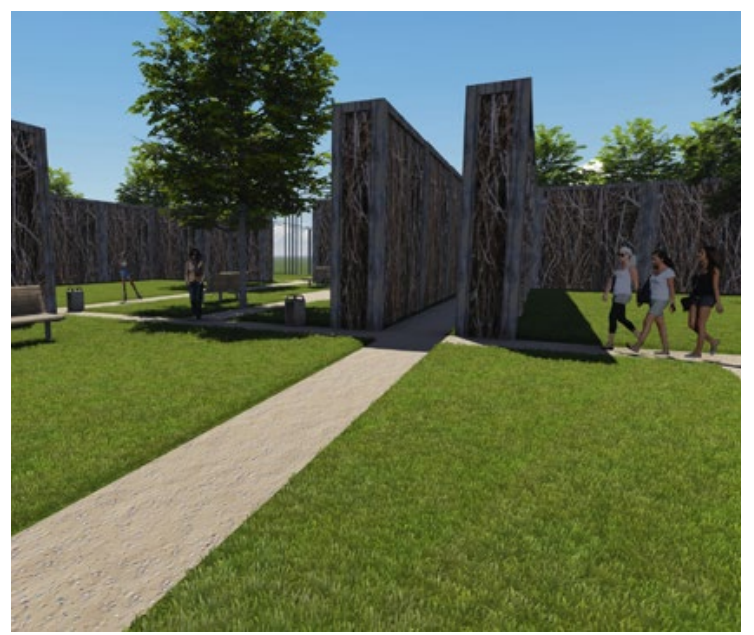

b

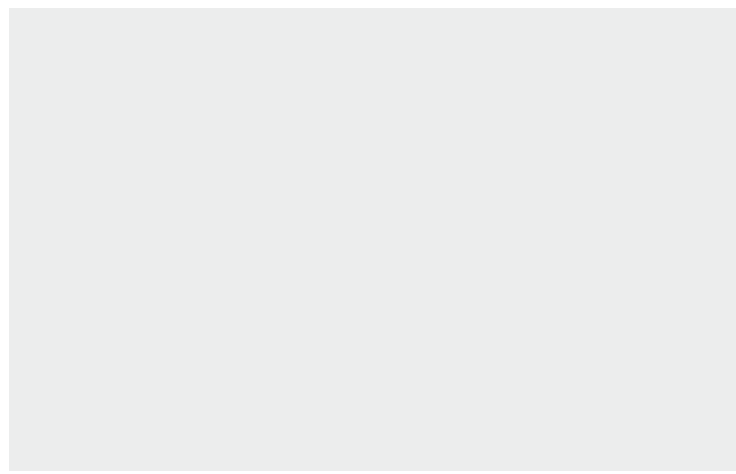

$\mathrm{d}$

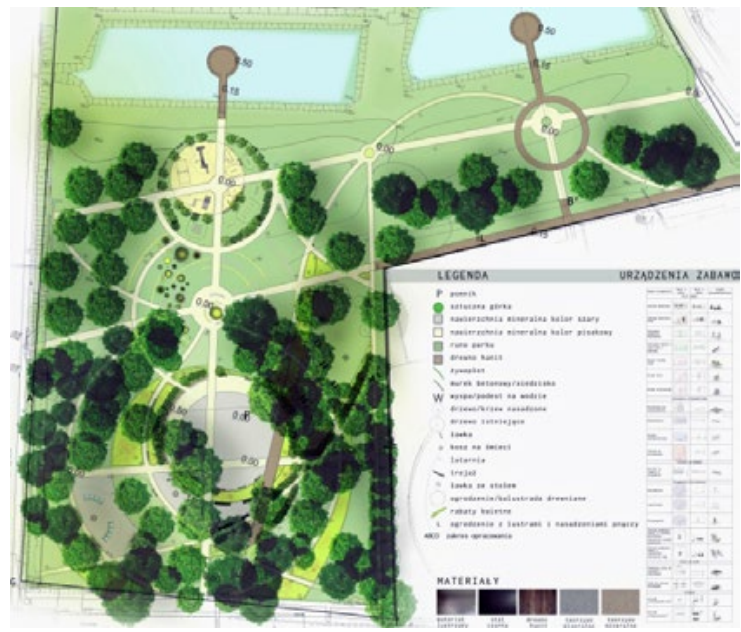

Fig. 2. Students's projects: a - Architectural and landscape view connections (A. Tekień, A. Michalis, S. Piszczatowski); b - Inspiration of Bazylian's garden historical composition (K. Manikało, I. Szpakowska, J. Zakrzewska); c - Healing and terapeutic functions of resort park (K. Sochacki, P. Sielawa, P. Rusiłowicz); d-Integration of new program with historical structure of town (Jarmołowska, Samełko, Lewsza).

Analyzing the designs allowed us to find the possibility to expand the functional programme of the existing one in the following forms:

- Integrating the new functional programme into historical structure of the town and including landscape solutions (architectonical and environmental) (Fig. 2a, 2c, 2d)

- Including the park in the natural setup in order to create walking paths that unite green spaces and the public ones in Supraśl (Fig. 2a, 2b, 2c)

- Integrating new facilities and gardens responsible for healing and therapeutic functions in the Town Park (Fig. 2a, 2c)

- Integrating a playground in form of recreation areas with devices and space for active plays for children and their education at the same time (Fig. 2b, 2d)

- Integrating the facilities and recreation devices and rehabilitation ones such as on open air gym for teenagers and elder people (Fig. 2d)

- Enabling the access to disabled people (Fig. 2d) 
Based on students' ideas we reached the conclusion that including historical composition of Bazylian Italian garden and the structure of the Town Park from the date of its creation in 19th century were the essential elements of the proposed students' designs.

\section{Conclusions}

The cooperation between The Town Council in Supraśl and Bialystok University of Technology in 2016 in order to find the idea how to revalorize the Town Park brought mutual benefits. Using the method of investigation on Bialystok University of Technology that link the research with practical classes in the department of Landscape Architecture. Obtaining a great amount of functional solutions to the park. It also gives the possibility to include in the programme of the Town Park in Supraśl new functions healing, therapeuticall, recreation ones together with its access and compositional and environmental values closely linked to the historical character of this park.

The conclusions from the analysis of projects and science work can be used by the Town to know the newest trends in designing the parts of the landscape architecture their habilitation and arrangement. They also give a chance to see different forms of designing adjusted to the localization and searching for the best solutions. They also help the investor to fulfill the expectations in issues such as functional park programme that face the designers and the contractors. Moreover those studies help in conservation and revalorization of the park. The conclusion from the students' projects allow also to include the historical and environmental elements.

The real value from this process is the possibility to introduce into the university curriculum the elements of issues and designs based on the real need of the local society. The students take a very active part in this kind of studies as they are real life, can be put into practice and they are in touch with real institutions and habitants, potential investors. Both the possibility of designing real places and studies (science work with lecturers) carried out by them can be used to cover the real needs of the local society [Januszkiewicz $2017 \mathrm{a}$ ].

\section{References}

[1] Bogdanowski J., 1999. Style, kompozycja i rewaloryzacja w polskiej sztuce ogrodowej. Wybrane problemy. Wyd. Politechnik Krakowskiej, Kraków

[2] Bończak-Kucharczyk E., Maroszek J., Kucharczyk K., 2000. Parki i ogrody zabytkowe w krajobrazie kulturowym Podlasia. Katalog parków i ogrodów zabytkowych dawnego województwa białostockiego stan z 1988 r. , Prace Białostockiego Towarzystwa Naukowego nr 47, Białystok

[3] Bończak-Kucharczyk E., Maroszek J., Białystok Park Zwierzyniecki, http://www.testowy.minigo.pl/index.php/page/bia-ystok-park-zwierzyniecki,§ (dostęp lipiec 2017)

[4] Ciołek G., 1978. Ogrody polskie (Wznowienie przygotował i uzupełniające rozdziały napisał Janusz Bogdanowski), Arkady, Warszawa

[5] Czałczyńska-Podolska M., 2016. Ogrody jordanowskie na tle współczesnych ogrodów dziecięcych. [w:] Park miejski - znaczenie w przestrzeni zurbanizowanej. Praca zbiorowa pod red. K. Hodor, K. Łakomy, Wydawnictwo PK, Kraków, 111-126

[6] Czubiński J., 2015. Revitalisation of historical urban and architectural ensembles in selected spa towns located in the valley of the river Prut in Hutsul Region. Rewitalizacja historycznych układów urbanistyczno-architektonicznych w wybranych miejscowościach uzdrowiskowych położonych w dolinie rzeki Prut na Huculszczyźnie. Space \& FORM. 23 (1)2015, 77-90

[7] Dąbski M., Dutkiewicz M., 2010. Przystosowanie ogrodu dla niewidomego użytkownika na przykładzie ogrodów sensorycznych w Bolestaszycach, Bucharzewie I Powsinie. Teka Komisji Architektury, Urbanistyki I Studiów Krajobrazowych - OL PAN. 2010, 7-17

[8] Dmitruk M., 2015. Ogrody lecznicze jako forma wspomagania terapii. Teka Komisji Architektury, Urbanistyki I Studiów Krajobrazowych - OL PAN. 2015.2, 15-21

[9] Dobrowolski R., Popławska M., 2003. Plan Supraśla z 1845 r. (komunikat), Małe Miasta. Przestrzenie pod red. M. Zemło, Collegium Suprasliense, Supraśl, 51-54

[10] Dobrowolski R., 2003. Początki miejskości Supraśla, Małe Miasta. Przestrzenie pod red. M. Zemło, Collegium Suprasliense, Supraśl, 321-340 
[11] Gawryluk D., 2015. Historical Public Parks in Podlasie and their Current Day Modernisation, Miestu Želdynų Formavimas (2015 1 (12)), 74-80

[12] Januszkiewicz J., 2017 a. Altanki, alejki, plac zabaw, stawy, nowe życie placu przed urzędem. [w:] Poranny, 02.06.2017, https://plus.poranny.pl/wiadomosci/a/altanki-alejki-plac-zabaw-stawy-nowe-zycie-placu-przed-urzedem,12137854 (dostęp: paździenik 2017)

[13] Januszkiewicz J., 2017 b. Burmistrz Radosław Dorbrowolski wierzy że Supraśl ocalał dzięki aniołom. [w:] Poranny, 03.07.2017, https://plus.poranny.pl/magazyn/a/burmistrz-radoslaw-dobrowolski-wierzy-ze-suprasl-ocalal-dzieki-aniolom,12213491 (dostęp: październik 2017)

[14] Kłopotowska A., Kłopotowski M., [w druku, maszynopis udostępniony przez autorów], Dotykowe modele architektoniczne w przestrzeniach polskich miast. Część l. Standardy. Część II. Realizacje.

[15] Kłopotowski M., 2017. Zalecenia projektowo-realizacyjne dla dotykowych modeli architektonicznych - prezentacja wygłoszona na seminarium naukowym Katedry Konstrukcji Budowlanych i Architektury Politechniki Białostockiej w dniu października 2017

[16] Kubecka M., 2016. Prosto z miasta Nałęczów. Recepta na uzdrowisko. Nałęczów dla wszystkich. Ścieżki kuracjuszy. Uzdrowisko przyszłości. Magazyn Miasta kultura/ludzie/przestrzeń, nr 3(15)2016, 120-125

[17] Leniartek M. K., 2015. Rewitalizacja parków zdrojowych zagrożeniem dla sfery materialnej i znaczeniowej miejscowości uzdrowiskowych na przykładzie uzdrowisk ziemi kłodzkiej. [w:] Dziedzictwo zagrożone, ogrody historyczne w Polsce, red. K. Hodor, K. Łakomy, Wyd. Politechniki Krakowskiej, Kraków, 73-90

[18] Łakomy K., 2012. Ogrody w krajobrazach miast (cz. 2, od poł. XVIII do XX w.), [w:] Historyczne i współczesne ogrody w krajobrazie miasta, red. A. Mitkowska, K. Hodor, K. Łakomy, Czasopismo Techniczne , z. 6-A, rok 109, Wyd. Politechniki Krakowskiej, Kraków

[19] Łodziński P., 2002, Lad przestrzeni zabudowy mieszkaniowej małego miasta na przykładzie Supraśla, rozprawa doktorska wykonana pod kierunkiem prof. dr. hab. inż. arch. K. Kuczy-Kuczyńskiego, Wydział Architektury Politechniki Warszawskiej, Warszawa

[20] Majdecki L., 1993. Ochrona i konserwacja zabytkowych założeń ogrodowych, Wydawnictwo Naukowe PWN, Warszawa

[21] Majdecki L., 2007. Historia ogrodów, t. 1 i 2, Wydawnictwo Naukowe PWN, Warszawa

[22] Myczkowski Z., Rymsza-Mazur W., 2012. Uwarunkowania konserwatorskie w planowaniu krajobrazu zabytkowego na przykładzie uzdrowiska w Swoszowicach. Teka Komisji Architektury, Urbanistyki I Studiów Krajobrazowych - OL PAN. 2012. VIII/1, 104-115

[23] Piróg M., 2011. Architektura drewniana w tożsamości uzdrowisk dolnośląskich. Teka Komisji Architektury, Urbanistyki I Studiów Krajobrazowych - OL PAN. 2011, 92-98

[24] Piróg M., 2013. Wartości architektury uzdrowiskowej w kontekście ochrony krajobrazu ozdrowisk dolnoślaskich. Teka Komisji Architektury, Urbanistyki I Studiów Krajobrazowych - OL PAN. 2013, IX/3, 37-44

[25] Pudelska K., Dutkiewicz M., Durlak W., Parzymies M., 2016. Ranga dawnych I współczesnyc ogrodów terapeutycznych. Acta Scientiarum Polonorum. Formatio Circumietus. 15(1)2016, 125-137

[26] Rutyna H., 2014. Resylience of a small health resort. Rezyliencja małego uzdrowiska. Space \& FORM. 22(2)2014, 153-166

[27] Souter-Brown G.., 2015. Landscape and Urban Design for Health and Well-Being. Using healing, sensory and therapeutic gardens. Routledge (Taylor and Francis Group), London and New York.

[28] Supraśl 500 lat., 2000, praca zbiorowa pod red. T. Ołdytowskiego, Towarzystwo Przyjaciół Suprasla, Białystok

[29] Supraśl, strona internetowa Urzędu Miasta w Supraślu, 2016. http://www.suprasl.pl/aktualnosci_edukacja/odtworza-supraski-park [dostęp wrzesień 2017]

[30] Węcławowicz-Bilska E., 2008a. Uzdrowiska polskie. Zagadnienia programowo-przestrzenne. Wydawnictwo PK, Kraków

[31] Węcławowicz-Bilska E., 2008b. "Serce miasta”, uzdrowiska, technopolis. Czasopismo Techniczne, z. 4-A, Wyd. Politechniki Krakowskiej, Kraków

[32] Winterbottom D., Wagenfeld A., 2015. Design for Healing Spaces. Therapeutic Gardens. Timber Press, Portland, London.

[33] Zachariasz A., 2006. Zieleń jako współczesny czynnik miastotwórczy ze szczególnym uwzględnieniem roli parków publicznych. Seria Architektura, monografia, 336, Wydawnictwo Politechniki Krakowskiej, Kraków

[34] Zachariasz A., 2007. Zabytkowe parki i ogrody publiczne we współczesnym krajobrazie - problemy rewaloryzacji. Red. J. Rylke, Przyroda i Miasto, t. X cz. I, Warszawa, 328-354

[35] Zachariasz A., 2008. Zabytkowe ogrody - problemy rewaloryzacji, utrzymania i zarządzania w świetle zaleceń karty florenckiej, Zarządzanie Krajobrazem Kulturowym, Prace Komisji Krajobrazu Kulturowego Nr 10, Komisja Krajobrazu Kulturowego PTG, Sosnowiec, 150-161. 